\title{
Analysing Single Women's Residential Choice in Tokyo by Using a Qualitative Method
}

\author{
KAMIYA Hiroo*, KAGEYAMA Honami**, and KINOSHITA Reiko*** \\ * Faculty of Letters, Kanazawa University, Kanazawa 920-1192, Japan \\ ** Faculty of Letters, Sugiyama Women's University, Nagoya 464-8662, Japan \\ *** Izumi High School, Yokohama 245-8553, Japan
}

\begin{abstract}
From the Japanese demographic data, it is evident that the category of single women is increasingly constituting a larger segment of the population. Thus far, policies pertaining to housing and social benefits have been targeted at nuclear families based on the "Asian style welfare state," and minimum attention has been given to single women. Therefore, in this paper, we attempt to address the factors affecting single women's residential choices by using in-depth interviews. In addition, in order to confirm the research results, triangulation methodologies are applied. Triangulation methods are conducted in two ways. First, my female colleague checks my (male) interpretations against the interview records. Second, my (male) interpretations are compared with the profiles appearing in a non-fiction work by a female writer. As a result, we observe that the residential choices of single women in Tokyo have the following characteristics. 1) Single women are rather myopic in their attitude toward work- and housing-related issues due to their unstable working conditions. 2) They are likely to value easy access to a railway station in their residential choice due to the geographical concentration of job opportunities in the city center and the long working hours. 3) They have limited housing options because most of the available housing stocks cater to nuclear families. Through the triangulation methodologies, other factors affecting their housing choices have been suggested: social contact with their parents and their relationships with their boyfriend. Additionally, the 1996 legislation reform for equal job opportunities and the effects of economic globalization on job opportunities for single women may have affected their working environment.
\end{abstract}

Key words: single women, residential choice, Tokyo, qualitative method

\section{Introduction}

The "Asian style welfare state" is characterized by greater emphasis on economic growth over welfare. A relatively abundant labor supply in the Japanese labor market prior to the 1970s, along with a growth-oriented social policy and the influence of the suburban nuclear family lifestyle of Western societies, a sociospatial division of labor has been established rapidly growing Japanese cities, i.e., husbands commute to work to the city center while their wives take up the domestic responsibilities. In this context, socalled Japanese employment system including age-based wage, strong loyalty to the company by employee, and long term employment in Japanese companies plays a pivotal role in such a sociospatial division of labor.

The low turnover rate of workers in Japanese companies implies that promotions to higher positions are given to those workers who show potential for greater contribution to the company for longer periods of time. This has resulted in a male-dominated labor management system in Japanese companies.

A steady increase in single households has been documented in Western societies since the 1950s. Hall et al. (1987) pointed out the demographic factors underlying the increasing number of single households. First, children become independent at much earlier age from their parents than before. Secondly, marriage is prolonged at older age. Thirdly, cohabitation is more common among young couples. Fourthly, the number of children is increasing. Fifthly, divorced house- 
holds become more common. Sixthly, population is aging rapidly. An increase in the number of single households stems from socioeconomic factors as well as demographic factors. These include the decline of the subsistence economysuch as small farmers, development of the service economy, and fulfillment of social security such as pension to sustain the aged life. The increased number of single households varies in terms of age and sex, such as households comprising the so-called "single" men or young women, middle-aged divorced households, and aged households. Ishikawa (1999) documented the spatial concentration of the aged households and business bachelors in Tokyo and the Keihanshin metropolitan area in Japan. Jutakutoshiseibikodan (1991) also studied the spatial concentration of single households from the perspective of housing requirements.

These studies contributed significantly to the study on the increasing of single households. However, single households comprising young people in their twenties and thirties also constitute a large segment of the population (Wakabayashi 2004). On the basis of life stage, such households are regarded as transient households that are on the threshold of forming nuclear families soon, and little attention has been paid to them. Nevertheless, postponing marriage implies an extended period of life as a single person, and it is considerably important to consider this changing demography of Japan.

In this paper, single working women are analysed by focusing on their residential choices using a qualitative method. In recent years, qualitative methods are widely used in geographical research. Qualitative analysis is more useful in situations that demand the analysis of human behavior based on the context and its concealed implications as a whole, and it complements the quantitative analysis by scrutinizing the variables independently. Social and cultural geographers have been rather eager to study cultural representation with a focus on gender and ethnicity by using qualitative methods (Winchester 1999: England 1993). Recently economic geographers tackling the embedness of economic actions have highlighted this methodological framework (Yeung 1997, 2003).

With regard to female workers and their lifestyles, they are considered to be in a marginalized position in Japanese society for various reasons. First they do not follow the traditionally defined gender roles of women in Japanese society, typified as quitting their jobs after marriage and assuming the role of a housewife. Secondly their position in the labor market is not on par with that of men in the male-dominated promotion system. Thirdly their housing demands are not met by the previous public housing policy. In addition, single women are excluded from the government's current employment and social policy.

Before moving to an explanation of the empirical research design, we briefly sketch the outline of qualitative methods and their problems in application, with reference to Baxter and Eyles (1997). Focus group interview, in-depth interview, participant observation and text analysis are known as commonly used methodologies in qualitative analysis. As statistical tests are applied in quantitative analysis, procedural rigidity is required in qualitative analysis. Baxter and Eyles (1997) indicated varied criterion to ensure rigidity in qualitative analysis. These are 1) plausible explanation why the used method is appropriate, 2) applying multiple methods (triangulation), 3) enough explanation on sampling respondents, 4) quotation of narratives, 5) detailed description on interview methods, 6) examining procedure of analysis, 7) observation for longer period, 8) repeated investigation, 9) cross check of research record by respondents, 10) plausible representation against the readers, 11) showing criterion to validate the findings obtained. The former four criteria are adopted in over the half of the 31 papers adopting qualitative methodology appearing over the past twelve years (Baxter and Eyle 1997). Reliability, replicability, transferability, and certainty are basic criteria of methodological rigidity.

Since this paper exclusively depended on interview records in extracting the factors affecting single women's residential choice, we attempt to search for methodological rigor.

\section{Research Method}

In-depth interviews were conducted in order to examine the factors affecting single women's 
Table 1. Profiles of the sample participants in the interviews

\begin{tabular}{|c|c|c|c|c|c|}
\hline Name & $\begin{array}{c}\text { Residence } \\
\text { (Ward or City) }\end{array}$ & Housing Type & $\begin{array}{l}\text { Hometown } \\
\text { (Prefecture) }\end{array}$ & Job & Cohabitator \\
\hline Yuriko & Setagaya, Tokyo & apartment & Tokyo & freelancer & Yes \\
\hline Sanae & Suginami, Tokyo & apartment & Fukushima & clerical worker & No \\
\hline Tomika & Edogawa, Tokyo & condominium & Hokkaido & copyright coordinator & Yes \\
\hline Yuko & Ota, Tokyo & apartment & Aichi & sales manager & No \\
\hline Satomi & $\begin{array}{l}\text { Yokohama, } \\
\text { Kanagawa }\end{array}$ & apartment & Chiba & programmer & No \\
\hline Michiko & Ota, Tokyo & condominium & Tokyo & bank clerk & No \\
\hline Manami & Chiba, Chiba & apartment & Chiba & $\begin{array}{l}\text { manufacturing } \\
\text { inspector }\end{array}$ & Yes \\
\hline Eri & Setagaya, Tokyo & apartment & Saitama & medical practitioner & Yes \\
\hline Sayaka & Chiba, Chiba & public housing & Tokyo & sales manager & Yes \\
\hline Miho & $\begin{array}{l}\text { Kawasaki, } \\
\text { Kanagawa }\end{array}$ & condominium & Akita & clerical worker & No \\
\hline
\end{tabular}

residential choices. Prior to the interview, a questionnaire survey was conducted among email users who worked on a full-time basis and were not married, aged between thirty and forty years old, living independently from parents. All of them worked and resided in the Tokyo metropolitan area. The respondents in the questionnaire survey were asked to join the focus group interview. Eleven interviewees were approached via e-mail. This implies that these respondents had higher educational degrees and earned more than the average female workers. In the focus group interview conducted in February 1998, the participants were asked to discuss various topics including their preferred housing type, working conditions, and their future plans.

During the second stage, each of the respondents was asked to participate in an in-depth interview. Ten out of eleven participants in the focus group interview participated in the indepth interview. Hereafter, my (male) interpretation is primarily based on the records of the in-depth interviews because the discourses articulated through the focus group interview do not differ significantly from those articulated in the in-depth interviews. In addition, in order to confirm the research results, triangulation methods were applied. Table 1 presents the profiles of the women included in the sample.

\section{Interpreting the Interview Records}

From the recorded interviews, I found that the single women's residential choices are characterized by the following three factors. First, they have rather uncertain prospects about their future plans. Second, they are likely to value easy access to railway stations due to the geographical concentration of job opportunities in the city center and long working hours. Third, they have limited housing options because housing stock in Japan almost exclusively caters to nuclear families.

\section{Uncertain prospects}

With regard to the first point, it is closely related with the gender role assigned to female workers. Although they refuse to accept the traditional gender role of Japanese women, it is not easy for them to find the alternative lifestyle. They are extremely busy with their professional occupations such that they do not have sufficient time to consider their future, which compels them to make their residential choices from a short-term perspective.

Yuriko described her future prospects as follows. Since both her sisters, younger and older, were single, she was concerned about her aging parents. Nonetheless, she expressed her desire to live independently because in the past, her parents had interfered in her private life. In short, she was ambivalent between worrying about her parents and leading an independent life away from them. In addition, she is uncertain about continuing her life with her boyfriend. 
I cannot imagine the situation one year later....

If something be happen to my parents or if they have health problems, I might be forced to move back to their home....

Well, since all of us (my sisters and I) are single, we can cope with such a situation....

Sanae said she would not marry in the near future.

I have no intention (of marriage)....

If you have been single for very long, wouldn't you feel bothered if someone were to come and live with you?

So when a friend comes home, I feel no inconvenience.

But after he/she has left, I feel more relaxed....

Tomika said she would purchase a condominium with her boyfriend and live there with him. However, she has no intention to be legally married. Nevertheless, she does not have any concrete plans about whether she will bear a child and is uncertain about the future of her current job.

The mortgage is going to last for thirtyfive years.

.......

But I am unsure whether I will live there for that long.

It is located exactly opposite the station, so it will be rather easy to let.

Presently, Yuko is enthusiastically working on building her career and is willing to be transferred from one place to another according to the demands of her company. The location of her job place has changed recently and she is presently planning to move her residence. Expecting to be forced to move again in the near future, she is looking for an easily accessible apartment.

The size of the apartment is immaterial. I only need sufficient space to accommodate the furniture.
Given that the rent of the apartment amounts to 150,000 yen, I would give greater priority to accessibility (to the workplace) than to size.

So I do not think about living there for long.

Anyhow, proximity to the workplace is the most important thing at the moment.

Satomi stated that she might feel awkward about marriage. But she has no strong desire to marry now. Through her work experience in the U.S., she knows that many single women in the U.S. live in detached houses. Hence, she would prefer a detached house for herself.

I may or may not marry....

I have no idea....

I think about my marriage, but perhaps it will not happen....

It is troublesome.

I have been making little effort to get married....

Will you tell me how I can get married.... .......

If the housing market in Japan undergoes drastic changes, I can buy a detached house.

Eri is currently living with her boyfriend. Immediately after quitting her job at a merchant bank, she began working as a chiropractor. She admitted to having a hectic daily life and complained that she has no time to think about the future course of life, such as whether to marry her boyfriend and where to live.

Really, I have no time to ponder....

I am so busy....

Time flies so fast.

Everyday, I work, eat, take a bath, and sleep...nothing more.

I have no time to ponder about my future, my private life.

Sayaka is currently living with her boyfriend. However, she has decided that she will not marry and become a housewife in the near future.

I am not sure what will happen to me. 
Perhaps, in the future, we will marry....

But now I do not want to....

Because he has no prospects to earn an income...

In practice, being single brings me strong feeling of not bound or restricted....

I think there is little difference between being married and being unmarried.

\section{Easy access to a railway station}

With regard to the second point, the traditional employment system in Japanese companies is structured in favor of male workers. Single women, who do not marry and continue to work on a full-time basis, have limited job opportunities in large and foreign companies; consequently, their workplaces tend to be concentrated in the city center. Therefore, when making residential choices, single women give higher priority to easy access to their office and to security. Although some of them stated that they want to move to another company, it is unlikely for them to change their residential preference.

Such residential preferences do not apply to all the respondents in this study. Some of them prefer a detached house in the suburbs. Moreover, the residential choices of single women are constrained by the structural factors of the housing market, such as the relative scarcity of small unit houses that are suitable for single women. The interview records of these women often underpin the tendencies with regard to residential choices.

In our interview with Tomika, she explained that she would give greater priority to the security of the accommodation because of a previous experience with a stalker on her way back from office.

I often use a taxi when coming back late in the night from my office.

I always keep an alarm bell in my handbag....

Next to the doorway of my house, you can see another one....

I always carry it with me....

Women seem to be less cautious....

My friend said to me, "you are excessively careful."

Do you agree with me?
One of the reasons for single women's nervousness about security is their late timing to return home from their office. When the eight employed women in our sample were questioned on this, they replied that they leave office at 19:10 and arrive home at 20:25 on an average weekday. One of them returned home as late as past midnight since she worked overtime three days a week. This is partly because the sample participants in this study are well educated and hold high positions in their companies. Regardless of their tasks in the company, it is evident that single women prioritize security when they decide on a place to live.

Tomika explained that she and her boyfriend chose to buy a condominium in the eastern part of Tokyo because it provided easy access to her office.

Since my boyfriend and I wish to get wellpaying jobs, we can't move to the outer suburb....

It will be particularly very difficult for me to commute if we move....

So we are forced to buy a condominium close to the subway station.

If we can earn more, we can buy a condominium closer to the office.

Yuko also mentioned that she prioritized easy access to her workplace in making a residential choice. She was recently transferred from her former office to a new workplace in the city center. She is currently looking for a new residence to shorten her commuting time. Transfers take place fairly often in her company; therefore, she is seeking an apartment along the Loop Line in Tokyo.

I'm now looking for a house....

The current apartment is so far from my office, as well as from the station.

Switching trains is very time-consuming....

Now, I take a bus to the nearest station, then take a JR line. At Shinagawa station, I change the train for the Loop Line.

It usually takes an hour and a quarter, but if the bus is delayed, it takes longer. 
From the interview record, it is unclear whether the workplaces of the single working women are concentrated in the city center. It is quite difficult to exactly determine the spatial characteristics of the local labor market at an individual level.

Satomi, who prefers country life, stated that she wants to live in the outer suburb of Tokyo if a job opportunity is available. Constrained by the commuting distance to her current office, she believes that it is rather difficult to move further away from her present residence. She complained about the relatively small stock of small unit apartments available for single women.

My office is along the railway line, so I would feel inconvenienced if I moved from here.

One of my friends chose to live in the inner suburb.... But I cannot....

I like the wooded environment and clean air... and sunshine.

I do not prefer the city life of Tokyo.

If my company is relocated to the countryside, I can enjoy rural life.

\section{Limited housing options}

With regard to the third point, the housing requirements of single working women are rather different from those of nuclear families or college students. They often have limited options for suitable housing available to them and face discriminative treatment by gatekeepers in the housing market.

Sanae related one of her worst experiences with a real estate agent.

This apartment was the second option. The first option presented by the real estate agent was....

......

The sales manager said to me, "Most of the residents of that apartment were Iranian people....

I think it will not be a good choice for you, a female customer."

Satomi, who is fluent in English and has worked in the U.S., compares the Japanese housing market with that in the U.S. In addition, her lack of faith is directed not only toward the gender-biased housing market but also toward the economic system and Japanese society in general.

I enjoy my life and am comfortable working in a global company.

But as for the housing options, I feel rather burdened by the traditional Japanese customs.

When I was in the U.S., I complained to my American friend that....

I said to her, "Japanese tradition does not appreciate single women who want to buy a detached house."

She then replied, "I know women with children are not welcomed, but why single women?"

The other day, I spoke to a real estate agent....

I said that developers should provide more apartment houses for women like me, who want apartments that are a little more spacious than those available for college students.

I live alone, so I don't need many small rooms in my apartment.

Michiko wanted to buy a relatively new condominium. She spoke of her difficulty in finding suitable property since the condominiums constructed during the bubble economy are not being traded in the market and the number of properties for single households is limited.

I could not find a new condominium in the market.

The housing stocks constructed a couple of years ago are so few.

Anyway, I decided to find a slightly older house.

I wanted to decide quickly.

Since the supply of condominiums for sale and rent has exceeded the demand after the burst of the bubble economy, the supply of properties for single households has been increasing. As a re- 
sult, single households now constitute a larger share of the housing market. Although the allocation requirements in public sector housing have been relaxed in recent times, single women are still at a disadvantage in the housing market.

\section{Testing by Triangulation}

The above mentioned interpretations of the indepth interviews were confirmed by using triangulation methods. First, my (Kamiya: male) interpretation of the interview records is checked by a (Kageyama: female) colleague. Another triangulation was carried out by comparing my (male) interpretation with the descriptions appearing in the work of a female writer of non-fiction.

\section{Bias in the interpretations of the researcher}

Before collating my interpretations with those of my colleague, it is useful to describe the background of the interpreters as well as the demographic differences in their gender and age, and the differences in their residential histories. I spent only one year in Tokyo and the rest of my life in Nagoya and Kanazawa. On the other hand, my colleague grew up in a non-metropolitan area and moved to Tokyo about ten years ago. Despite the differences in our backgrounds, being academic geographers, we have a more comprehensive understanding of the housing market, female employment, and the transportation problems in Tokyo.

My colleague insists that my interpretations are insufficient with regard to the following points. First, it does not take into account the residential histories of the respondents and their degree of satisfaction with their dwellings. Such factors may affect the residential choice; however, they are not unique to the residential choices of single women. In order to address this matter, we require more empirical studies to compare the factors affecting the residential choices of single households with those of nuclear families.

Second, according to her interpretations of the interview records, the relationship of single women with their parents is very important in the residential decision. My omission of this factor may typify the gender bias in the interpreta- tion of the research results. In Japan, caring for the elderly is substantially a woman's responsibility; hence, male interpreters are likely to ignore this factor.

Finally, she pointed out that boyfriends might influence women's residential decisions. Recalling the process of my analysis, I appreciated the possibility that the residential choices of single women might be affected by their relationship with their boyfriends. However, the relationship with the boyfriend appears intractable to me because defining the term "single" is rather difficult. The interviewed women are between thirty and forty years of age and each woman shares a different relationship with her boyfriend: some have bought condominiums and live together with their boyfriends, others date regularly during weekends, while some others are considering living independently from their boyfriends. Since single women are faced with situations that are rather different, it appears unlikely that merely their boyfriends would affect their residential choices.

\section{Comparing the interview records with the work of non-fiction}

As I mentioned in the beginning of the paper, single women and single households came into prominence around the $1980 \mathrm{~s}$, and they have been focused on in academic papers and books. In this paragraph, a non-fiction work that is based on an interview is analysed by comparing the residential environment described in the book with that articulated in our in-depth interviews.

Junko Matsubara published the book titled "Women's dwelling" in 1987, and this book gained immense popularity among women in their thirties and forties in the Tokyo metropolitan area. After this book, she continued to publish essays and non-fiction works, focusing primarily on single women like her.

Table 2 lists the profiles of the characters appearing in her work. While reading this book, the readers may get the impression that the author appreciates single women. For example, she wrote the following on the back cover of the book.

A stylist in Minami-Aoyama, a local bu- 
Table 2. Profiles of the characters appearing in the work by Junko Matsubara

\begin{tabular}{|c|c|c|c|}
\hline & Age & Chapter Title & Housing Type \\
\hline Chapter 1 & approx. 38 & $\begin{array}{l}\text { A pleasant dwelling is essential for the job } \\
\text { A stylist in Minami-Aoyama }\end{array}$ & rented condominium \\
\hline Chapter 2 & 33 & $\begin{array}{l}\text { Forced to move } \\
\text { A former high school teacher in Harajuku }\end{array}$ & apartment \\
\hline Chapter 3 & $40^{\prime}$ & $\begin{array}{l}\text { Her room is filled with brand goods } \\
\text { A local bureaucrat in Azagaya }\end{array}$ & apartment \\
\hline Chapter 4 & 29 & $\begin{array}{l}\text { Wants to leave her parents' house } \\
\text { Living with parents in Setagaya }\end{array}$ & detached house \\
\hline Chapter 5 & 37 & $\begin{array}{l}\text { Finds it bothersome to renew her apartment contract } \\
\text { A cooking consultant at Jiyugaoka }\end{array}$ & rented condominium \\
\hline Chapter 6 & 33 & $\begin{array}{l}\text { A room colored in pink } \\
\text { A hairdresser at Hakusan }\end{array}$ & rented condominium \\
\hline Chapter 7 & 36 & $\begin{array}{l}\text { Cautious when living as a single woman } \\
\text { A career women in Nakano }\end{array}$ & rented condominium \\
\hline Chapter 8 & 37 & $\begin{array}{l}\text { Place rented in order to recover from jet lag } \\
\text { A purser at the intl. line at Ryogoku }\end{array}$ & rented condominium \\
\hline Chapter 9 & 42 & $\begin{array}{l}\text { Another change of condominiums } \\
\text { An editor in Bunkyo-ku }\end{array}$ & condominium \\
\hline Chapter 10 & 33 & $\begin{array}{l}\text { Paying five hundred dollars to parents } \\
\text { Living with parents in Nerima-ku }\end{array}$ & detached house \\
\hline Chapter 11 & 46 & $\begin{array}{l}\text { I am lucky in finding real estate } \\
\text { A designer in Shibuya }\end{array}$ & condominium \\
\hline Chapter 12 & 40 & $\begin{array}{l}\text { Gifted with money but has no boyfriend } \\
\text { A translator in the suburb }\end{array}$ & condominium \\
\hline
\end{tabular}

reaucrat in Azagaya, a working woman living with her parents in Setagaya, a purser at an international line at Ryogoku, a designer in Shibuya....

I visited twelve women and scrutinized their rooms, I asked them why they had settled down there.

Through these interviews, I want to analyze the future life courses of women in Tokyo.

What do they do after the interview is finished?

Do they continue to live in the same place as before?

It is so worrying.

I report the current housing scenario to the best of my knowledge.

The housing options reflect their life courses.

I have no way of knowing where they might have settled down later.

But it is certain that they are trying their best.
From these descriptions, one can ascertain that her book sympathizes with those who continue to "be single," i.e., continue to work. Therefore, this book is a good case for this comparative study.

"Women's dwelling" was published in 1987, a year before the enactment of the Equal Opportunity Law. One of the reasons why her book gained wide acceptance is that it was an attempt to improve the status of working women in Japan.

I will briefly examine the differences among the profiles of the single women in my research and those in her non-fiction work. The main differences are summarized as follows. First the women in the non-fiction are more likely to work on a freelance basis. Secondly they are older than the interviewed women. Thirdly their residences are more scattered all around Tokyo than those of our sample. Fourthly they are not working on a career course. Fifthly they are not highly educated, and earn lower incomes.

I carefully read through the work of non-fiction in order to determine whether the three factors derived from interview records are applica- 
ble to it. I will compare these points one after the other.

With regard to the first point, women in this work of non-fiction do not question the traditional gender roles in Japanese society. Alternatively, it is possible that Junko Matsubara did not question the women on this topic. They did mention their unclear future, as did the women in our sample; however, this was not based on skepticism against the traditional gender roles.

Such differences may be due to differences in the ages and the jobs held by the participants in the two samples. They also arise from the fact that some women in the book are living with their parents.

While in my interview record, access to the office is found to be an extremely important factor in single women's residential choices, the women appearing in Matsubara's work do not consider it as an essential factor in their decision-making. This is because most of these women are freelancers. However, easy access to the workplace and security are sometimes referred to as important factors in the non-fiction work.

Finally, in the non-fiction work, it is unclear whether single women have limited options with regard to housing availability. In other words, her book takes up the issue of the dwellings of single women, but not their housing problem.

In brief, the three factors are not clearly described in this work of non-fiction. While this may be attributable to the difference in the two samples with regard to age and jobs, it is estimated that the status of single women has changed substantially after 1987, when the book was written. The Equal Opportunity Law enacted in 1986 and the changing service economy may have encouraged women to work. Global companies tend to locate their head offices in the center of Tokyo's city area (Morikawa 1999), and more single women find their jobs in these global businesses than married women do. These trends may explain the job shift among single women during the last two decades. However, the relationship between job opportunities for women and the spatial pattern of residences still remains a topic for future study.

\section{Conclusion}

The residential choices of single women were analysed using records of in-depth interviews. The analysis revealed three factors affecting their residential decisions. First, they tend to make short- or medium-term decisions because they do not have a clear vision about marriage and career. Second, they are likely to prioritize easy access to a railway station because their job opportunities tend to be geographically concentrated in the city center, and they work for long hours and return home late. Third, they face the problem of limited housing options since the previous housing policy in Japan was targeted at married households and the housing market for single women was extremely limited.

In order to test the reliability of the above conclusion, triangulation methodologies were applied. After triangulation, other factors affecting single women's residential choices were also suggested further. One of these factors is the changing urban economy of Tokyo, which may enhance the working condition of single women.

\section{Acknowledgments}

Part of this paper is based on Kamiya et al. (1999). This paper was presented at the $3^{\text {rd }}$ International Conference of Asia Scholars, Singapore, in August 2003. This study was supported by Grants-in-Aid for Scientific Research by JSPS ((B) (1), No. 14380026).

(Received 3 February 2006) (Accepted 31 July 2006)

\section{References}

Baxter, J., and Eyles, J. 1997. Evaluating qualitative research in social geography: Establishing 'rigor' in interview analysis. Transactions of the Institute of British Geographers 22: 505-525.

England, K. 1993. Suburban pink collar ghettos: The spatial entrapment of women?. Annals of the Association of American Geographers 83: 225-242.

Hall, R., Ogden, O., and Hill, C. 1987. The pattern and structure of one-person households in England and Wales and France. International Journal of Population Geography 3: 161-181.

Ishikawa, Y. 1999. Keihanshin no nidai-toshiken ni okeru tandokusetai (Single households in the Keihin and Keihanshin metropolitan areas). In 
Daitoshiken-kenkyu Vol. II, ed. K. Narita, 204223, Tokyo: Taimeido. (J)

Jutakutoshi-seibikodan. 1991. Shutoken niokeru tanshin kyojusha nikansuru chosa houkokusho (Report on one-person households in Tokyo metropolitan area). Tokyo: Jutakutoshi-seibikodan. (J)

Kamiya, H. Kageyama, H., and Kinoshita, R. 1999. Tokyo daitoshiken ni okeru dokushinjosei no kyojuchi sentaku (Single Women's Residential Choice). Geographical Report of the Kanazawa University 9: 17-32. (J)

Morikawa, D. 1999. Gaishikei kigyo no ritti karamita kokunai niokeru toshi kaisoukouzou (City hierarchy in Japan from the perspective of the office location of the global companies). Unpublished master thesis submitted to the Department of Geography, Kanazawa University. (J)

Wakabayashi, Y. 2004. Raifu suteiji karamita Tokyo-ken no hataraku josei to kyojuchi sentaku (Working women and their residential choice in Tokyo metropolitan area viewing from life stage). In Hataraku josei no toshikuukan (Urban space of working women in Tokyo) ed. Y. Yui, $\mathrm{H}$. Kamiya, Y. Wakabayashi, and T. Nakazawa, 76-89. Tokyo: Kokon shoin (J)

Winchester, H.P.M. 1999. Interviews and questionnaires as mixed methods in population geography: The case of lone fathers in Newcastle, Australia. Professional Geographers 51: 60-67.

Yeung, H. W. 1997. Critical realism and realist research in human geography: A method or a philosophy in search of a method?. Progress in Human Geography 21: 51-74.

Yeung, H. W. 2003. Practicing new economic geographies: A methodological examination. Annals of the Association of American Geographers 93: 442-462.

(J): written in Japanese 